Article

\title{
Assessment of the Mechanism for Mining Technology Transfer in the Area: Loopholes in ISA Practice and Its Mining Code
}

\author{
Yu Ning
}

\author{
Guanghua Law School, Zhejiang University, Hangzhou 310000, China; ningyusysu@163.com
}

\begin{abstract}
Draft commercial exploitation regulations have been on the agenda of the ISA since several 15-year exploration contracts expired a few years ago. Given the ineffective implementation in practice and the ignored chapter in several mining regulations on the transfer of mining technology, the future Enterprise and developing countries may take a more positive approach to the transfer of mining technology by striking a delicate balance between the provisions on the protection of intellectual property and those on capacity building under the framework of UNCLOS and the 1994 Agreement, through reciprocal and mutual beneficial means such as direct technology purchasing and investment cooperation. The International Seabed Authority, as the competent inter-governmental organization, has the duty to foster favorable conditions for such transfer.
\end{abstract}

Keywords: transfer of mining technology; commercial condition; protection of intellectual property; direct technology purchasing; investment cooperation

Citation: Ning, Y. Assessment of the Mechanism for Mining Technology Transfer in the Area: Loopholes in ISA Practice and Its Mining Code. Sustainability 2021, 13, 7005. https://doi.org/10.3390/su13137005

Academic Editors: Keyuan Zou and Yen-Chiang Chang

Received: 12 April 2021

Accepted: 10 May 2021

Published: 22 June 2021

Publisher's Note: MDPI stays neutral with regard to jurisdictional claims in published maps and institutional affiliations.

Copyright: (C) 2021 by the author. Licensee MDPI, Basel, Switzerland. This article is an open access article distributed under the terms and conditions of the Creative Commons Attribution (CC BY) license (https:/ / creativecommons.org/licenses/by/ $4.0 /)$.

\section{Introduction}

By now the international community has gradually realized the economic and strategic value of the mineral resources in the deep seabed. After decades of negotiations to balance the interests of industrialized countries and developing countries, the principle of common heritage of mankind had been established to govern human activities in the international seabed beyond national jurisdiction. For a long time in history, marine technologies were mainly in the hands of industrialized States. In order to facilitate capacity building for developing States, a regime of technology transfer was set up in Part XIV of and Annex III to the United Nations Convention on the Law of the Sea of 10 December 1982 (UNCLOS), as well as Agreement relating to the Implementation of Part XI of the United Nations Convention on the Law of the Sea of 10 December 1982 (the 1994 Agreement). In addition to the general regulations in Part XIV 'Development and Transfer of Marine Technology', Article 144 is especially applicable to the Area under UNCLOS. However, after the adoption of Section 5 of the 1994 Agreement, the provisions of Annex III, Article 5 of UNCLOS shall not apply, which means that the transfer of technology in the Area is no longer mandatory.

In order to regulate activities in the Area, the International Seabed Authority (the Authority/ISA), as the competent international organisation, has formulated three Exploration Regulations, namely Regulations on Prospecting and Exploration for Polymetallic Nodules in the Area (ISBA/19/C/17), Regulations on Prospecting and Exploration for Polymetallic Sulphides in the Area (ISBA/16/A/12/Rev.1) and Regulations on Prospecting and Exploration for Cobalt-rich Ferromanganese Crusts in the Area (ISBA/18/A/11) [1]. Article 3 of the above Exploration Regulations all advocate training programmes in technology transfer under the context of Article 144 of UNCLOS. To date, ISA has signed 30 exploration contracts [2]. Some of these contracts will expire in the near future. It may suggest that certain contractors will commence commercial deep seabed mining soon which will eventually generate direct economic benefits [3] (p. 486). In accordance with UNCLOS and the 1994 Agreement, since 2014, ISA has been working to develop regulations for exploitation of mineral resources in the Area [4]. ISA has also received some comments on the "Draft Regulations on Exploitation of Mineral Resources in the Area (ISBA/25/C/WP.1) (Draft 
Exploitation Regulations)" [5]. Throughout the Draft Exploitation Regulations, there are two provisions which directly refer to technology transfer. In Regulation 2, technology transfer is treated as one of the fundamental policies and principles. Additionally, Regulation 63 requests the Council to provide incentives, including financial incentives, to stimulate technology transfer.

In the process of negotiation by the Council on exploitation regulations, the Assembly approved a Strategic Plan for the International Seabed Authority for the period 2019-2023 (ISBA/24/A/10) [6]. In this Strategic Plan, Strategic Direction 5 titled "Build capacity for developing States" stressed on the needs of developing States and funding. It is noted that Strategic Direction 5 refers merely to capacity building while Part XIV of UNCLOS stipulates capacity building as well as transfer of technology. Similarly, Strategic Direction 6.3 focuses on marine scientific and technological training provided by Article 144(2)(b) of UNCLOS and in the meantime, it ignores transfer of technology provided by Article 144(2)(a).

None of the above-mentioned legal documents defines technology transfer and enumerates specific implementation measures, except for training programmes. As Ariel W. Gonzalez pointed out, the key reason for the failure to implement the re-gime of transfer of technology lies in that the thirteen articles of Part XIV of UNCLOS do not set out a clear-cut regime, especially the rights and obligations [7]. Following the generation of economic benefits from commercial exploitation of deep seabed mining, how to implement the transfer of technology to the Enterprise and developing States will be the focal point of commercial exploitation era on top of the issue of benefit sharing. The key to untying the knot in the implementation of the transfer of technology is to clarify the rights and obligations of donors and recipients. The article focuses on solving the intellectual property issues which are the top concerns for donors, and solving the transaction price and flexible cooperation that recipients are most concerned about.

\section{The Lack of Transfer of Technology in Practice and Documents of ISA}

What is technology transfer? UNCLOS, as "a Constitution for the Oceans" [8,9] (pp. xxxiii, vii), has not given a definition. The provisions of Annex III, Article 5, of UNCLOS provides a definition about "technology" in the context of technology transfer. However, the definition was considered too broad [10] (p. 244), and this article has no longer applied according to the provisions of the 1994 Agreement.

\subsection{Transfer of Technology and Transfer of Scientific Knowledge}

Part XIV of UNCLOS provides general provisions on technology transfer for all maritime areas. In accordance with Article 268 in Part XIV, technology transfer should include "the acquisition, evaluation and dissemination of marine technological knowledge" [11] and "the development of appropriate marine technology" [11]. Article 144, as the provision specialized in technology transfer in the Area, is consistent with the whole provisions of UNCLOS [11]:

"Article 144 Transfer of technology

1. The Authority shall take measures in accordance with this Convention:

(a) to acquire technology and scientific knowledge relating to activities in the Area; and

(b) to promote and encourage the transfer to developing States of such technology and scientific knowledge so that all States Parties benefit therefrom.

2. To this end the Authority and States Parties shall cooperate in promoting the transfer of technology and scientific knowledge relating to activities in the Area so that the Enterprise and all States Parties may benefit therefrom. In particular they shall initiate and promote:

(a) programmes for the transfer of technology to the Enterprise and to developing States with regard to activities in the Area, including, inter alia, 
facilitating the access of the Enterprise and of developing States to the relevant technology, under fair and reasonable terms and conditions; measures directed towards the advancement of the technology of the Enterprise and the domestic technology of developing States, particularly by providing opportunities to personnel from the Enterprise and from developing States for training in marine science and technology and for their full participation in activities in the Area."

This provision has two requirements: one is the transfer of the technology, and the other is the transfer of scientific knowledge.

Clearly, in the context of "technology transfer (in broad sense)", whether in the titles of Part XIV or Article 144, there are two essential elements: "transfer of technology" (the key term in the concrete provisions) and "transfer of scientific knowledge" (the key term in the concrete provisions). In other words, technology transfer in broad sense includes not only the transfer of technology itself, but also the transfer of scientific knowledge related to technology. To be viable, the Enterprise would get access to seabed mining technology and the technical expertise necessary to effectively utilize that technology [12] (p. 176). Compared with Article 268(d), we can conclude that training personnel from developing States or of the Enterprise is a means of scientific knowledge transfer. In addition, although Annex III, Article 5 of UNCLOS is no longer applicable, and its scope of "technology" is considered to be too broad, the connotation of "technology" including "technical knowhow" listed in this provision may be used as a reference to better interpret the whole provisions relating to technology transfer in the context of UNCLOS.

As is well known, the opposition to mandatory transfer of technology from major industrialized States (such as Italy, the United States, the United Kingdom) still continues. In order to facilitate wider participation in UNCLOS, the 1994 Agreement modified the compulsory provisions. The transfer of technology is no longer mandatory according to the 1994 Agreement [13] (p. 198). In addition to the provisions of Article 144 of UNCLOS, transfer of technology relating to the activities in the Area shall be governed by Section 5 of the 1994 Agreement [14]. Without exception, the provisions of Section 5 of the 1994 Agreement emphasize the commercial conditions for acquisition of deep seabed mining technology by the Enterprise and developing States. In addition, the provisions provide that States Parties shall promote international technical and scientific cooperation by training, technical assistance and scientific cooperation [14].

Through the above provisions, we can see that technology transfer in a broad sense, under the context of UNCLOS, includes both of the transfer of technology itself and the transfer of scientific knowledge relating to relevant technology, and training is one of the main patterns of transfer of scientific knowledge. In combination with Articles 273 and 274, the "transfer of technology itself" involves skills [11] as well as technical documentation on the relevant equipment, machinery, devices and processes [11], while the "transfer of scientific knowledge" contains training [11] and the acquisition of necessary equipment, processes, plant and other technical know-how [11].

\subsection{Focus on Training and Neglect of Transfer of Technology in ISA Practice}

After the entry into force of UNCLOS, many international organizations have taken measures to promote the transfer of technology. Such as, the Intergovernmental Oceanographic Commission (IOC) adopted Criteria and Guidelines on the Transfer of Marine Technology, United Nations General Assembly (UNGA) stresses the rationale for facilitating transfer of marine technology in several Resolutions. It is worthy to note that many references of documents of these international organizations which only stressed "training activities" were insufficient to install capacity-building - and even less transfer of marine technology - in the multilateral agenda [7] (p. 356). For example, ISA has paid more attention to training activities for personnel of the Authority as well as of developing States and has ignored the transfer of technology itself in practice, especially the patented mining technology which is the key technology in exploration and exploitation in the Area. 
Since 2013, a total of 134 training locations have been provided [15]. The training obligation is set out in the exploration contracts. In other words, the right to explore mineral resources in the Area and the duty to provide training opportunities for personnel of the Authority and of developing States go hand in hand. The training programme has developed into various types, which is helpful for developing States to get access to technical knowledge about activities in the Area, and thus contributes to improve human resources for developing States. Compared with the training obligation, there is no concrete duty about transfer of technology itself in each exploration contract.

However, a phenomenon which cannot be ignored is that those developing States accepting training opportunities still have no capability to explore or exploit mineral resources in the Area. For instance, Nigeria is such a state. This country has seized many training opportunities, such as provided by Companhia De Pesquisa de Recursos Minerais (CPRM) [16], but Nigeria still lacks the mining technology to take part in activities in the Area. Kenya too. Michael Lodge, the then Deputy to the Secretary-General of the ISA, expressed concerns over the lack of participation by African States in recent years especially with the fact that among 26 deep sea exploration contracts approved by the Authority, none was sponsored by an African State [17]. The technology involved in the mineral recovery from the sea is complex, expensive, and relatively recent [10] (p. 173). Most developing States, like African States, do not possess the mining technology. It appears that almost only developed States have the institutions, vessels, instruments, expertise, and financial resources to undertake marine scientific research [18] (p. 308). It is obvious that the lack of expertise or technical knowledge by developing States will constrain their engagement in mining activities, however, only if they possess relevant mining technology, can they fully participate in the activities in the Area.

\subsection{Ignored Chapter on Transfer of Technology in Several Important ISA Documents}

So far, the mining technology has mainly been controlled by the developed States. Acknowledging the challenges during the transition from exploration to exploitation, how to effectively organize and control activities in the Area and ensure developing States to fully participate in the activities are urgent tasks for the Authority.

\subsubsection{Strategic Plan and Other Relevant Documents}

The Assembly of the Authority adopted the International Seabed Authority's Strategic Plan for the period 2019-2023 (the Strategic Plan) at its twenty-fourth session [19]. One of the expected outcomes of this strategic plan is "the ability to acquire technology and scientific knowledge relating to activities in the Area and to promote and encourage the transfer to developing States of such technology and scientific knowledge so that all States Parties benefit therefrom" [20]. Notwithstanding the expected outcome, the strategic directions which are critical for the Authority to realize its mission have not completely reflected it. Among the nine strategic directions, Strategic Direction 5 and Strategic Direction 6 are closely related to the regime of technology transfer (in broad sense). The title of Strategic Direction 5 is to "build capacity for developing States" [20]. However, the title of Part XIV, the corresponding part in UNCLOS, is "development and transfer of marine technology" [11]. They both emphasize the development of technology/ capacity-building; nevertheless, Strategic Direction 5 does not highlight the chapter on the transfer of marine technology of UNCLOS. Specifically, in Strategic Direction 5.4, the Authority regarded training programmes as a means of realizing capacity-building and solely paid attention to the training programmes provided by Contractors. In Strategic Direction 6.3, it refers directly to Article 144 of UNCLOS, but regrettably, this provision also only focuses on training which refers to Article 144(2)(b), and neglects the transfer of technology and acquirement of such technology in Article 144(2)(a).

In response to the Strategic Plan, a draft High-Level Action Plan is developed to implement and achieve the Strategic Directions. The corresponding High-Level Actions identify the needs of developing States and stress the means for promoting training oppor- 
tunities. Additionally, the draft Performance Indicators (PI) has been conceived to enable monitoring and measuring the achievements of the Strategic Plan throughout its five-year life [21]. PI 5.5 provides that particular attention should be given to the number of qualified personnel who have benefited from training funded through the Endowment Fund for Marine Scientific Research in the Area [21]. The quality and quantity of personnel benefited from training programmes is the focus in the documents of the Authority. All of the above documents neglect the transfer of technology itself.

\subsubsection{Draft Exploitation Regulations}

In order to regulate effectively mining exploitation in the Area, the Legal and Technical Commission of the Authority prepared Draft Exploitation Regulations. In this document, the Authority regards "participation in revenues by the Authority and the transfer of technology to the Enterprise and developing States" [22] as one of fundamental policies and principles. However, throughout the whole document, there has no provision on concrete rules about the transfer of technology. What the Authority may be advocated to do about the transfer of technology is only providing incentives including financial incentives to those Contractors and developing States or their nationals to stimulate the transfer of technology [22]. The document does not even enumerate the specific content of the transfer of technology as Article 274 of UNCLOS. In contrast, the Contractor's training obligation is specified in more detail in Part III, Section 7 in this document. Every exploitation contract should be attached with the approved training plan. The training plan can be modified or amended when the Contractor, the Authority and the sponsoring State or States have concluded mutual agreement, and the new training plan should be conducted by the Contractor [22]. In other words, providing training opportunities to the personnel of the Authority or of developing States is a mandatory obligation for Contractors if they want to conduct exploitation of mineral resources in the Area. As UNCLOS is a package deal, for attracting more industrialized countries to join, the 1994 Agreement actually has amended the provisions of Annex III, Article 5 of UNCLOS, which means that the transfer of technology is no longer a compulsory obligation, but it still advocates transfer of technology, as Article 144 of UNCLOS. Furthermore, this Draft Exploitation Regulations also has not provided any concrete measures about the transfer of technology. Therefore, how to implement the regime of transfer of technology provided by UNCLOS is a real problem especially during the transition from exploration to commercial exploitation.

\section{Patented Mining Technology Purchasing: Direct Solution}

The Intergovernmental Oceanographic Commission of UNESCO (IOC), as a competent international organization in the field of transfer of marine technology recognized by the United Nations, has developed the Criteria and Guidelines on Transfer of Marine Technology (CGTMT) for States Parties to implement the regime of transfer of marine technology in Part XIV of UNCLOS [23]. In the CGTMT, IOC recognized that "such transfer should be done free of charge, or at a reduced rate for the benefit of the recipient country" [23]. Transfer of mining technology in the Area is a specific pattern of transfer of marine technology, so such transfer should also be guided by the CGTMT as a general rule. However, the potential significance of the ability to exploit the mineral riches of the deep seabed is considered by many experts to be critical for the further industrial expansion of the world's economy [10] (p. 173). Do the industrialized States have probability to transfer mining technology to the Enterprise or developing States free of charge or at a reduced rate under the context of no mandatory obligation? The provisions of Section 5 of the 1994 Agreement changed from Annex III, Article 5 of UNCLOS can tell us the answer.

\subsection{On Fair and Reasonable Commercial Terms and Conditions}

As for mandatory obligation under Annex III, Article 5 of UNCLOS, the provisions of Section 5 of the 1994 Agreement provide that the transfer of technology should be "on fair and reasonable commercial terms and conditions" [14]. In addition to the provisions 
of Article 144 of UNCLOS providing transfer of technology should be "under fair and reasonable terms and conditions" [11] and provisions of Article 266 stipulating "fair and reasonable terms and conditions" [11], transfer of technology should be governed by principles offered by the provisions of Section 5 of the 1994 Agreement which requires transfer of technology should be conducted "on fair and reasonable commercial terms and conditions" [14].

\subsubsection{The Meaning of "Commercial"}

The term "commercial" we should draw special attention to stands for the condition of transfer accepted by developed States. In general sense, "commercial" is mainly for the exchange of goods or for money [24,25] (pp. 38, 485). In the commercial condition, it is unlikely to accept that the transfer of technology is conducted "free of charge or at a reduced rate for the benefit of the recipient country" [23]. It demands reciprocal interests.

Long before the Third UN Conference on the Law of the Sea, polymetallic nodules were considered as an important source of strategic mineral resources in the future by industrialized countries [26] (p. 339). Due to the economic benefit resulted from mineral resources in the Area, the relevant technology is developed interest-oriented. The industrialized States have invested a lot of money and human resources in mining technology and they are not willing to transfer such technology to developing States without any return. Both for practical reasons and for reasons of principle, industrialized States would not agree to any system requiring the mandatory transfer of technology that had largely been developed by private enterprises operating under free market principles [12] (p. 176). Inversely, they usually tend to apply for a patent to protect such mining technology from infringement, especially the core technology [27].

\subsubsection{Purchasing by Paying a Certain Price and Establishing Dedicated Fund}

In order to obtain the patented mining technology, one of the advised ways is to purchase such technology under fair and reasonable commercial terms and conditions. Directly, the developing States purchase the patented mining technology by paying a certain price. The price should be determined by both parties to the transaction under the guidance of ISA. Additionally, one of the interpretative terms to help us to understand the condition of transfer is the provision "on the open market" [14]. The price should follow the basic principle of open market for encouraging such scientific research, at least not to discourage the enthusiam for such invention. As a proposal by the Federal Republic of Germany noted during the ninth session of the Third UN Conference on the Law of the Sea, "Fair and reasonable commercial terms and conditions are conditions of the kind actually agreed in practice in comparable cases. In absence of any comparable case, the price agreed should be such as to make an adequate contribution towards recouping development costs. This includes the cost of development work which has not been successful as well as the cost of work necessary to establish a basis of knowledge for carrying out a given project." [12] (p. 679-680) Surely, the price should be certainly favorable for developing States or the Enterprise under the principle of the open market, at least cheaper than transferring to others.

Nevertheless, developing States just lack capital. In order to solve the problem for better implementation of transfer of technology, the Authority should establish dedicated fund to assist developing States in purchasing such patented technology. A long time ago, the International Maritime Organization (IMO) formulated the 1971 International Convention on the Establishment of an International Fund for Compensation for Oil Pollution Damage - although this was not to facilitate implementation-more to provide a common safety net [28] (p. 316). The Authority should learn the lessons from this practice of the IMO. At present, the Authority provides Endowment Fund to promote and encourage the conduct of collaborative marine scientific research in the Area for the benefit of humankind through two main activities: (a) by supporting the participation of qualified scientists and technical personnel from developing countries in marine scientific 
research programmes and activities; (b) by providing opportunities to these scientists to participate in relevant initiatives [29]. The Endowment Fund aims at facilitating developing countries' participation, but furthermore, ISA should offer the assistance to developing States to purchase patented mining technology which they hardly develop. The dedicated funding mechanism for purchasing patented mining technology shall have two ways: (a) by providing fund directly; (b) by offering loan arrangement. The Dedicated Fund shall consist of voluntary donations by member States and partial fees paid by Contractors. An Advisory Panel shall be appointed by the Authority to specialize in evaluating such applications. The application shall submit to the Secretariat and be determined by the Legal and Technical Commission according to the advice from the Advisory Panel. The applicants must be the member States of the Authority.

(a) Providing fund directly. For purchasing fundamental devices or observation equipment and facilities, the Authority can provide a certain fund (for example, not exceed $20 \%$ of total price) for a developing country. The developing country should submit an application with detailed information (such as, purpose, method of utilization, transaction price, comparison of transaction price and develop cost or the reason of can't develop, etc.) under each kind of transaction. The purchasing willingness and price must be demonstrated to be accepted by counterparty. Moreover, the developing country should stipulate it has qualified scientists and technical personnel to better utilize, even develop, such devices or equipment. However, ISA should give prior consideration to offer loan unless the developing country in a poor condition to repay the loan.

(b) Offering loan arrangement. For purchasing other patented mining technology, the Authority shall offer a certain loan for a developing country if it applies. The amount of loan should be based on the total transaction price, the debt paying ability of the developing country and the debt paying plan submitted by the developing country. Additionally, the issuance of loan cannot impact the integral operation of the Fund and the potential loan application of other developing countries. The loan application should be submitted accompanied by detailed information (such as, purpose, method of utilization, transaction price, the demonstration of debt paying ability, the reasonable debt paying plan, etc.). Besides, the Authority can operate with other international organizations, such as IOC and World Bank, for providing such fund to assist developing States more systematically to obtain patented mining technologies.

\subsection{The Effective Protection of Intellectual Property Rights}

With the more and more prominent role of technology on economy as well as other aspects, the world community pays more and more attention to protection of intellectual property rights. The establishment of World Intellectual Property Organization (WIPO) which has 193 member States nowadays is the best example. WIPO developed the International Patent System to assist applicants in seeking patent protection internationally for their inventions and to facilitate public access to a wealth of technical information relating to those inventions [30]. Whether developed countries or developing countries have legislated a series of regulations to protect intellectual property rights. Patent right is one of critical intellectual property rights, which should be protected for incentive to develop technology accordingly beneficial for economy. Although the protection of patent rights should contribute to the transfer of technology according to article 7 of TRIPS, we hardly find an example of successful patent assignment or licence in deep seabed mining technology through searching in the website of WIPO, ISA as well as IOC [27].

\subsubsection{The Meaning of "Patent"}

The sense of granting "patent" is granting the right to exclude others from making, using, marketing, selling, offering for sale, or importing an invention for a specified period (generally 20 years from the date of filing) [24] (p. 1234). It is intended to protect the rights of the appropriate technology of the states, enterprises, or individuals who have developed 
the technology and hold the patent [12] (p. 189). Paragraph 1(b) of Section 5 of the 1994 Agreement which aimed at improving participation of developed States stipulates that the Enterprise or its joint venture or developing States seeking to acquire deep seabed mining technology should obtain such technology "on fair and reasonable commercial terms and conditions, consistent with the effective protection of intellectual property rights" [14]. This provision not only reflects the requirements of developed States on the patented mining technology transfer, but also is a compromise between interests of developing States and developed States. Patented mining technology is that technology holders (states, individuals or enterprises) have invested lots of asset and human resources to develop and have intended to earn the benefit from utilizing this technology in mining or selling to others. Therefore, effective protection of intellectual property rights seems to be an integral element of deep seabed mining regime.

\subsubsection{Patent Assignment and Patent Licence}

ISA can cooperate with other international organizations, especially specialized in intellectual property rights protection, such as WIPO, to implement the effective protection of patented mining technology, including facilitating patent assignment and patent licence.

(a) Patent assignment. A transfer of rights of ownership is known as an "assignment", which might include all rights in the patent or a more limited interest such as the exclusive right to a geographical area [31] (p. 60). Throughout the practice of countries, patent assignment usually occurs in the case of employment relationship [32] (p. 447). In the scope of deep seabed mining technology, there are two patterns of patent assignment. The first and most critical pattern is that individuals or corporates as patentees or inventors transfer their entire rights to developing countries who have assistance relationship but not essential employment with them. Taking an example, some scientific researchers or skilled personnel from developed States assisted developing States to do some marine research, and during the period of assistance, these scientific researchers or skilled personnel have invented relevant deep seabed mining technology and therefore have a patent, and then ISA shall accelerate the patent assignment to developing States under reasonable payment. In the context of assistance, because developing States offer certain research conditions for these inventors, similarly with employment relationship, it is easier to reach an agreement on such assignment. This way is helpful for developing States to obtain such patented mining technology and relating know-how, and beneficial for their capacity-building. Another is patent transferring from a Contractor directly to others. Such assignment is almost impossible to take place because of assignment covering entire rights of a patent, unless the profit from assignment exceeding the profit from deep seabed mining according to rationalism and market mechanism. However, as long as the view "mining resources in deep seabed regarded as important strategic assets" has not been changed, such assignment is unlikely to occur. On the contrast, patent licence is more practical.

(b) Patent licence. Compared with assignment, patent licence authorizes licensee limited rights to practice the invention in respective area. Yet the inventor still retains the ownership of the patent. A licence can be exclusive (only one licencee has the right to practice the claimed invention) or nonexclusive [31] (p. 61). Sometimes, under the circumstance of an exclusive licence, a licencee may sublicense others, but it is not the main pattern. In order to benefit more developing counties and effectively activate technology market, we advise ISA to foster favorable conditions for nonexclusive licence, particularly some mining technologies associated with environmental protection in the process of deep seabed mining. It is worthy to note, due to the principle of sovereignty, compulsory licence cannot be applied in all circumstances, even related to environmental protection. However, ISA might have rights to authorize a Contractor to utilize certain patented technology under the situation of urgent environmental protection for the interests of mankind as a whole. Definitely, this needs a further 
discussion and agreement authorizing such power among member States. The following conditions shall be respected under the consideration of such authorization: (i) The Contractor has already taken all measures as possible as he can to prevent such pollution; (ii) The proposed user has made efforts to obtain patent licence from the patentee on reasonable commercial terms and conditions and that such efforts have not been successful within a reasonable period of time [33]; (iii) Such authority shall be considered on its individual merits [33], and determined by the Council of ISA; (iv) The patent holders, suppliers and respective sponsoring State or States (if has), should be informed as quickly as possible, and they shall be paid adequate remuneration taking in account the economic value of the authorization [33] and the reason of such emergency; (v) The scope and duration of such use shall be limited to the purpose for which it was authorized [33], and the patented technology cannot be applied on other activities even invention of other technologies based on such patented technology, otherwise it will be regarded as an infringement; (vi) If the proposed user has been aware that his mining activities might cause such pollution without taking such patented technology but still were carried out, and thus resulted in the emergency, at the same time of taking measures of such authorization, ISA shall impose on him a punitive payment.

The next noteworthy problem is the situation that holders and suppliers of patented mining technology sometimes are not the same. That is to say, the Contractors are sometimes not the patent holders. There are practical difficulties for the commercial operators to transfer patented mining technology, especially if they are not owners of the technology in question [12] (p. 188). In the era of legalization of intellectual property protection, a Contractor, obtaining the patented mining technology on the premise of following relevant patent law, for example, through patent assignment or patent licence with certain payment, shall not transfer such technology in violating the protection of intellectual property.

As noted in TRIPS, the protection and enforcement of intellectual property rights should contribute to the transfer of technology [33]. Only through collaboration of free market principle and protection of intellectual property as well as the common heritage of mankind principle, can transfer of technology operate effectively and eventually benefit mankind as a whole.

\section{Investment Cooperation: Indirect Solution}

Either the Enterprise or most developing States lack both funds and technologies to conduct mining activities in the Area. Under the guidance of basic principle of the common heritage of mankind, how to better implement the regime of transfer of marine technology, in particular the patented mining technology, so that all States may benefit therefrom, especially developing States, is one of the problems that need to be solved urgently, particularly in the coming era of commercial exploitation. In addition to purchase patented mining technology directly, operating a joint venture to obtain the necessary mining technology within the present framework provided by UNCLOS and the 1994 Agreement is a practical choice.

\subsection{Seize the Superiority on Activities in "Reserved Areas" to Negotiate: for the Enterprise}

In October 2012, a proposal aimed at entering into negotiation to form a joint venture with the Enterprise based on sound commercial principles, to develop eight of the reserved area blocks in the Clarion-Clipperton Zone in the Pacific, was submitted by Nautilus Minerals Inc. (Nautilus), a company incorporated in Canada [34]. After a series of debates during the 19th Session of ISA, the Council reached agreement which reads "it is premature for the Enterprise to function independently" [35]. This is the first proposal related to form a joint venture with the Enterprise. To date, there has been no joint venture with the Enterprise. Nevertheless, with the exploitation era is coming, the Enterprise, as the mechanism through which the Authority can fulfill its mandate of generating benefits from 
the Area as the common heritage of mankind, should consider how to possess necessary funds and technologies to commerce commercial exploitation.

As is known, "the Enterprise shall conduct its initial deep seabed mining operations through joint ventures" [14] according to the provisions provided by Annex, Section 2 of the 1994 Agreement. Additionally, the Enterprise has no capacity to operate mining activities due to the shortage of capital and technology. The proposal by Nautilus has presented us a good cooperation model, though it failed for a number of reasons. Via a joint venture with Contractors (not limited to developing States, although taking into consideration the benefit of developing States, according to UNCLOS and the 1994 Agreement) who have been proved to have necessary funds and mining technologies, the Enterprise can solve the practical problems to explore and exploit, especially accessing the patented mining technologies through certain designed provisions, at least the non-exclusive patent licence. Let us take the example based on the discussion on the first joint venture proposal, irrespective of other factors. In Business Proposal Heads of Agreement by Nautilus, there are several concrete clauses providing approximate costs of each programme and funds supported by Nautilus, and it refers that they shall focus on participating interests, financial and technical contributions and others in the 2015 Programme [34]. As well, in related report by the Secretary-General, he noted the costs incurred by the Enterprise associated with this proposal would be borne by Nautilus [36]. It is a pity that both parties, mainly the Enterprise, have no mention of anything about transfer of marine technology to the Enterprise. Although capital is really very important in conducting mining activities, the Enterprise should draw more attention to the patented mining technology which is more vital and harder to obtain. In accordance with UNCLOS and its Annex III, the reserved area is exclusively for the Enterprise and developing States. Other countries or entities who are eligible to conduct mining operations shall only manage to build up a joint venture with the Enterprise or partnership with developing States. Furthermore, the priority of the Enterprise with regard to mining activities in the reserved area is for every State and every entity, including developing States. This is the biggest negotiating asset possessed by the Enterprise. Maybe the Enterprise should seize the superiority to negotiate with Contractors on transfer of marine technology, especially the patented mining technology. Because only when the Enterprise grasps the necessary patented mining technologies, could it have ability to operate independently in the Area, other than to cooperate with other countries for no other reason than technology. As a representative of Tonga noticed, if the Enterprise could not fulfill its mandate of ensuring the resources of the deep seabed were preserved as the common heritage of mankind, it would serve no purpose [37]. Definitely, both the reserved area and the Enterprise are served for the benefit of mankind as a whole, so only when the Enterprise or developing States directly master such mining technology can they fully participate in the activities in the Area and benefit therefrom. Why not the Enterprise make concessions in terms of financial benefits and pay more attention to the acquisition of mining technology? As the view of Siyoong Yoo, the main question in deep seabed mining development is if we do have the right technology available at the right time and with the right price [38] (pp. 1078-1083). For the Enterprise, utilizing a joint venture to access to the necessary technology is the best choice. Similarly, if an applicant decided to offer shares in a joint venture with the Enterprise instead of reserved area in the case of polymetallic sulphides (PMS) and cobalt-rich crusts (CRC) [39], the Enterprise should be more inclined to acquire the patented mining technology than purely monetary benefit in considering the shares.

Besides, when the Enterprise possesses the mining technologies, it shall prefer to transfer to developing States which may need and request under the principle of common heritage of mankind.

\subsection{Utilize "Reserved Areas" to Build up Partnership with Developed States: for Developing States}

As stated above, the reserved area is served exclusively for the Enterprise and developing States to realize the equitable benefit-sharing from the Area. If the Enterprise has 
no intention to conduct activities in applied reserved area, such area should be solely for developing States.

As of January 2019, six developing countries have taken advantage of the provisions in UNCLOS to sponsor exploration activities in the reserved areas, covering 427,495 sq. $\mathrm{km}$, in the circumstance of a total of 1,315,633 sq. km originally contributed to polymetallic nodules (PMN) reserved areas and $3000 \mathrm{sq}$. $\mathrm{km}$ to CRC [39]. Complying with the provisions of UNCLOS and its Annex, as well as the 1994 Agreement, the allocated reserved areas have been provided for developing States without exception. As for those developing States lacking of financial and technical capacity to enter into exploration or exploitation independently, the system of "reserved areas" is the greatest advantage for them to utilize to seek for partnership with developed States.

In fact, both the first and second contractor with exploration rights in the reserved areas are the combination of developing States and developed States (actually the entities from developed States). For instance, the first contractor Nauru Ocean Resources Inc. (NORI) benefited in its technical team from the experience of leaders of four international consortiums (Ocean Management Incorporation, Kennecott Exploration Consortium, Ocean Minerals Company and Ocean Mining Associates) which developed and successfully carried out trial deep-sea mining systems to collect nodules in the Clarion-Clipperton Zone in the 1970s [40]. This is the most direct cooperation means by which developing States can utilize relevant technologies to carry out activities. However, the ownership of such patented mining technologies still belongs to these entities. Fortunately, Nauru, as a sponsoring state, has been aware of the importance of access to marine technology. At the beginning of the sponsorship agreement drafted by Nauru and NORI, Nauru insisted on scientific and technical assistance, in addition to training and recruitment programmes for its nationals to effectively participate in the exploration activities. Such scientific and technical assistance should include "promoting and funding programmes of scientific, educational and technical assistance" [41], which is different from pure technical assistance free of charge and take sponsorship as consideration. This is de facto transfer of marine technology in UNCLOS. Despite the purpose of such technical assistance is for "increasing the State's capacity to protect and preserve the marine environment within the State's own exclusive economic zone" [41], marine technology applied on activities in marine area under national jurisdiction and beyond national jurisdiction have something in common, so that such marine technology might be applied on activities in the Area directly. Besides, Nauru can further develop mining technology on the basis of such technology and thus save a number of research grant and time. Definitely, it is better that if Nauru can propose NORI to transfer some patented mining technologies, even at the expense of part of royalty payments. In any case, NORI represents a pattern for developing States taking advantage of reserved areas to build up partnership with developed States (entities) to access the necessary mining technology. Analogous to NORI, while Tonga should not focus merely on participation in deep seabed activities nominally or monetary benefits, such as royalty payment, it lacked political will and awareness of proactive acquisition of transfer of marine technology, in particular the patented mining technology, as a transaction term. It is exactly a need to move from the passive approach of waiting for the transfer of marine technology to active attitude for access to such technology through a more dynamic, integrated and forward-looking marine technology policy [42,43] (pp. 692, 326). Developing States, like Tonga, should make full use of "reserved areas" to quest for the transfer of marine technology under mutual benefits, only through which can they effectively and actually participate in deep seabed mining in accordance with the spirit of UNCLOS and the 1994 Agreement as well as mining codes.

\subsection{South-South Cooperation with Approximate Political Benefits}

Comparatively, the possibility of success for South-South Cooperation is bigger since they are likely to have approximate political benefits, at least against the predominance of developed countries in deep seabed mining. So far, there are so many organizations or 
programmes operated for promoting collaboration amongst developing countries, such as the Group of 77.

On the one hand, developing countries can seek cooperation with developing States possessing deep seabed mining experiences and technologies. It is worth pointing out, there have been 2 Contractors sponsored by developing States, namely China and India, as pioneer investors in a total of seven Contractors in the Area, despite one intergovernmental consortium composed of developing States and developed States. In addition, among the total 30 contracts related to exploration in the Area, 14 of these contracts are sponsored by developing States, accounted for nearly half. India is a well-known developing country rich in technology in respect of deep seabed exploration. Take the cooperation between African countries and India as an example. Most African countries are poor in economy and technology, due to various reasons including political and historical, but this does not indicate that they have no interest in deep seabed mining. Thus, they have been proactive in seeking cooperation with other countries, in particular with India for the geographical and political reasons. The Indian Ocean Rim Association (IORA) is one of the best platforms, which is established on the basis of promoting cooperation in the Indian Ocean Region, since several African countries and India are the member states of IORA. Especially, academic, science \& technology and blue economy, including but not limited to minerals, are the two dominant priorities and focus areas identified by India during the period of its chairmanship. On a morning meeting during the first familiarization visit to India by IORA members' journalists, which several African countries, like Indonesia and South Africa, have taken part in, Mohan Shukla, the chief of the external affairs at Bharti Enterprises Ltd., said capacity building initiatives of IORA region countries was possible through technology transfer [44]. African countries shall set up workshops or forums with India to obtain skilled expertise and technology under the framework of IORA. Meanwhile, dialogue partners, including China and Egypt, of IORA, provide valuable assistance in the field of technology transfer, technical cooperation and so on [45]. African States also shall take measures to acquire technology transfer via the platform.

On the other hand, developing States can collaborate with each other which need and request the necessary mining technology. Though some developing countries have no enough capacity to conduct deep seabed mining activities independently, they have exactly developed some basic related marine technology. They shall take cooperative action by various means, such as technology exchange, patent licence including exclusive and non-exclusive. The complexities of surveying, prospecting, exploration and eventual exploitation and processing merely point to the fact that deep seabed mining requires immense technological capabilities [42] (p. 692). For example, Country A possessed unmanned research submersible which can withstand water pressure at a depth of 5000 meters but cannot handle the incidence of submarine thermal energy. Whilst Country $B$ developed one technology which can solve the problem of surveying against submarine thermal energy, and on the contrast, it just lacks the technology workable under water pressure at such depth. The two countries can set up collaboration by technology exchange in respect of the research cost with mutual interests. It is so important that developing States can save a lot of research cost and time, and thus accelerates their whole deep seabed mining process.

\section{Conclusions}

Conducting mining activities in the Area needs a number of funds and complex hightechnologies, which actually constraints developing States' participation. Reviewing the practice and several mining regulations, the regime of transfer of technology seems to be a loophole. With the coming era of commercial exploitation, how to effectively implement the transfer of mining technology for facilitating full participation of developing States and thus beneficial for mankind as a whole shall be one of the main focuses. Since UNCLOS and the 1994 Agreement definitely have stipulated the commercial conditions and protection of intellectual property on transfer of technology, the Enterprise and developing States 
should shift their passive waiting to active acquisition by utilizing various cooperation under the setting conditions. For the Enterprise and developing States, they should take full advantage of the regime of "reserved areas" to seek cooperation means with developed States for access to necessary patented mining technologies. Furthermore, developing States can try their best to build up partnership with other developing States possessing certain patented mining technology though such technology is not enough mature to be applied to mining activities, especially under the framework of relevant organizations. Such partnership will be comparatively easier to foster because they usually have some common political targets and benefits. Besides, the Authority, should foster favorable conditions to facilitate technology transfer, and collaborate with other organizations, such as IOC, World Bank, WIPO, to effectively and actually implement the transfer.

It is not impossible to implement the transfer of technology under the framework of UNCLOS and the 1994 Agreement. The pivot is reciprocity. On the premise of free market and intellectual property protection, the Enterprise and developing States should abandon their view of obtainment at a reduced rate or even free of charge, due to the massive financial and human resources in developing such technology. Only when the transfer of technology, in particular the patented technology, has been conducted in the context of commercial conditions and protection of intellectual property, can the regime of technology transfer be effectively implemented. Only when the transfer of technology has been effectively implemented, can the regime of deep seabed mining operate comprehensively, and can the principle of common heritage be realized in the future.

Funding: This paper is part of a research project funded by China's National Social Sciences Foundation (18VHQ002).

Institutional Review Board Statement: Not applicable.

Informed Consent Statement: Not applicable.

Data Availability Statement: The data presented in this study are openly available in website, reference number.

Acknowledgments: The author is grateful to Keyuan Zou (University of Central Lancashire) for his insightful comments and suggestions towards improving my manuscript.

Conflicts of Interest: The author declares no conflict of interest.

\section{References}

1. International Seabed Authority. Available online: https://isa.org.jm/index.php/mining-code/regulations (accessed on 24 March 2021).

2. International Seabed Authority. Available online: https:/ / isa.org.jm/exploration-contracts (accessed on 24 March 2021).

3. Le, J.T.; Levin, L.A.; Carson, R.T. Incorporating Ecosystem Services into Environmental Management of Deep-seabed Mining. Deep Sea Res. Part II Top. Stud. Oceanogr. 2017, 137, 486-503. [CrossRef]

4. International Seabed Authority. Available online: https://www.isa.org.jm/mining-code/ongoing-development-regulationsexploitation-mineral-resources-area (accessed on 24 March 2021).

5. International Seabed Authority. Comments on the Draft Regulations on the Exploitation of Mineral Resources in the Area (ISBA/26/C/2). Available online: https:/ / isa.org.jm/files/files/documents/26-c-2-en.pdf (accessed on 24 March 2021).

6. International Seabed Authority. Available online: https:/ / isa.org.jm/strategic-plan (accessed on 24 March 2021).

7. Gonzalez, A.W. Cutting a Gordian Knot? Towards a Practical and Realistic Scheme for the Transfer of Marine Technology. In Law, Science E Ocean Management; Nordquist, M.H., Long, R., Heidar, T.H., Moore, J.N., Eds.; Martinus Nijhoff Publishers: Boston, MA, USA, 2007; pp. 345-380.

8. UN. The Law of the Sea: Official Text of the United Nations Convention on the Law of the Sea with Annexes and Index; UN: New York, NY, USA, 1983; p. xxxiii.

9. Proelss, A. (Ed.) United Nations Convention on the Law of the Sea a Commentary; C. H. Beck·Hart·Nomos: Portland, OR, USA, 2017; p. vii.

10. Stavridis, J. Marine Technology Transfer and the Law of the Sea. Ph.D. Thesis, The Fletcher School of Law and Diplomacy, West Palm Beach, FL, USA, 1984; pp. 244, 173.

11. United Nations. United Nations Convention on the Law of the Sea of 10 December 1982. Available online: https:/ /www.un.org/ Depts/los/convention_agreements/texts/unclos/closindx.htm (accessed on 24 March 2021). 
12. Nandan, S.N. (Ed.) United Nations Convention on the Law of the Sea 1982 A Commentary; Martinus Nijhoff Publishers: Boston, MA, USA, 2003; Volume VI, pp. 176, 188-189, 679-680.

13. Nelson, L.D.M. The New Deep Sea-bed Mining Regime. Int. J. Mar. Coast. Law 1995, 10, 189-203. [CrossRef]

14. United Nations. Implementation of Part XI of the United Nations Convention on the Law of the Sea of 10 December 1982 . Available online: https:/ / www.un.org/Depts/los/convention_agreements/texts/unclos/closindx.htm (accessed on 24 March 2021).

15. International Seabed Authority. Available online: https://isa.org.jm/training (accessed on 24 March 2021).

16. International Seabed Authority. Available online: https://www.isa.org.jm/training/companhia-de-pesquisa-de-recursosminerais-cprm (accessed on 24 March 2021).

17. International Seabed Authority. Available online: https://www.isa.org.jm/news/african-states-encouraged-participate-allaspects-work-authority (accessed on 24 March 2021).

18. Long, R. Marine Science Capacity Building and Technology Transfer: Rights and Duties go Hand in Hand under the 1982 UNCLOS. In Law, Science E Ocean Management; Nordquist, M.H., Long, R., Heidar, T.H., Moore, J.N., Eds.; Martinus Nijhoff Publishers: Boston, MA, USA, 2007; pp. 299-312.

19. International Seabed Authority. Decision of the Assembly of the International Seabed Authority Relating to the Strategic Plan of the Authority for the Period 2019-2023; ISBA/24/A/10; ISBA: Kingston, Jamaica, 2018.

20. International Seabed Authority. Strategic Plan of the International Seabed Authority for the Period 2019-2023; ISBA/24/A/10; ISBA: Kingston, Jamaica, 2018.

21. International Seabed Authority. Implementation of the Strategic Plan of the International Seabed Authority: Draft Performance Indicators for the period 2019-2023 (ISBA/25/A/5). Available online: https://isa.org.jm/files/files/documents/isba25_a5-e.pdf (accessed on 24 March 2021).

22. International Seabed Authority. Draft Regulations on Exploitation of Mineral Resources in the Area (ISBA/25/C/WP.1). Available online: https://isa.org.jm/files/files/documents/isba_25_c_wp1-e_0.pdf (accessed on 24 March 2021).

23. IOC. Advisory Body of Experts on the Law of the Sea. In IOC Criteria and Guidelines on the Transfer of Marine Technology (CGTMT); United Nations Educational, Scientific and Cultural Organization: Paris, France, 2005; pp. 3, 10.

24. Garner, B.A. (Ed.) Black's Law Dictionary, 9th ed.; West, A Thomson Reuters Business: St. Paul, MN, USA, 2009 ; pp. 38, 1234.

25. Sheppard, S.M. (Ed.) Bouvier Law Dictionary; Wolters Kluwer Law \& Business: New York, NY, USA, $2012 ;$ p. 485.

26. Sohn, L.B.; Juras, K.G.; Noyes, J.E.; Franckx, E. The Law of the Sea in a Nutshell, 2nd ed.; West Academic Publishing: St. Paul, MN, USA, 2010; p. 339.

27. World Intellectual Property Organization. Available online: https://patentscope2.wipo.int/search/en/result.jsf?_vid=JP1-KON1 P7-94932 (accessed on 24 March 2021).

28. Freestone, D. Capacity Building and the Implementation of the Law of the Sea Convention: A View from the World Bank. In Law, Science E Ocean Management; Nordquist, M.H., Long, R., Heidar, T.H., Moore, J.N., Eds.; Martinus Nijhoff Publishers: Boston, MA, USA, 2007; pp. 313-344.

29. International Seabed Authority. Available online: https://www.isa.org.jm/contractors/endowment-fund (accessed on 24 March 2021).

30. World Intellectual Property Organization. Available online: https://www.wipo.int/pct/en/ (accessed on 24 March 2021).

31. Durham, A.L. Patent Law Essentials: A Concise Guide, 5th ed.; Praeger: Santa Barbara, CA, USA, 2018 ; pp. 60-61.

32. Emily, A. Assigned all my Rights away: The Overuse of Assignment Provisions in Contracts for Patent Rights. Iowa Law Rev. 2018, 104, 447-490.

33. World Trade Organization. Agreement on Trade-Related Aspects of Intellectual Property Rights (TRIPS) (as Amended on 23 January 2017). Available online: https:/ / www.wto.org/english/docs_e/legal_e/31bis_trips_01_e.htm (accessed on 24 March 2021).

34. International Seabed Authority. Proposal for a Joint Venture Operation with the Enterprise; ISBA/19/C/4; ISBA: Kingston, Jamaica, 2013.

35. International Seabed Authority. Available online: https://isa.org.jm/news/isa-council-considers-secretariat-note-regulatoryframework-nodules-exploitation (accessed on 24 March 2021).

36. International Seabed Authority. Considerations Relating to a Proposal by Nautilus Minerals Inc. for a Joint Venture Operation with the Enterprise; ISBA/19/C/6; ISBA: Kingston, Jamaica, 2013.

37. International Seabed Authority. Council Debates Proposal for Joint Venture with the Enterprise; SB/19/12; ISBA: Kingston, Jamaica, 2013.

38. Yoo, S. Technology Transfer Strategy of Developing Countries: The Case of Deep Seabed Mining Technology in Korea; Ocean Conference Record; IEEE: New York, NY, USA, 1995; pp. 1078-1083.

39. International Seabed Authority: Current Status of the Reserved Areas with the International Seabed Authority, Policy Brief. January 2019. Available online: https:/ / isa.org.jm/document/policy-brief-012019 (accessed on 24 March 2021).

40. Legal and Technical Commission. Report and Recommendations to the Council of the International Seabed Authority Relating to an Application for the Approval of a Plan of Work for Exploration by Nauru Ocean Resources Inc.; ISBA/17/C/9; ISBA: Kingston, Jamaica, 2011.

41. Nauru. Draft Sponsorship Agreement as a Means of Satisfying State Obligations under Part XI of the United Nations Convention on the Law of the Sea; Annex of Proposal to Seek an Advisory Opinion from the Seabed Disputes Chamber of the International Tribunal for the Law of the Sea on Matters Regarding Sponsoring State Responsibility and Liability; ISBA/16/C/6; ISBA: Kingston, Jamaica, 2010. 
42. Egede, E. African States and Participation in Deep Seabed Mining: Problems and Prospects. Int. J. Mar. Coast. Law 2009, 24, 683-712. [CrossRef]

43. Levy, J.-P. Towards an Integrated Marine Policy in Developing Countries. Mar. Policy 1988, 12, 326-342. [CrossRef]

44. Daily, I. Account of First Familiarization Visit to India by IORA Members' Journalists. 28 December 2017. Available online: https://www.iora.int/media/23880/irannewspaper13813.pdf (accessed on 25 March 2021).

45. IORA. Dialogue Partners. Available online: https:/ / www.iora.int/en/about/dialogue-partners (accessed on 25 March 2021). 